\title{
Mungbean (Vigna radiata L.): A Promising Nutritive Source for Livestock Feeding Supplements
}

\author{
Samir Attia Nagadi \\ Department of Arid Land Agriculture, Faculty of Meteorology, Environment \& Arid Land \\ Agriculture, King Abdulaziz University, Jeddah, Saudi Arabia \\ snagadi@kau.edu.sa
}

\begin{abstract}
This study was carried out to evaluate and compare the nutritive characteristics and the amino acids and fatty acids profiles of four Mungbean verities from China, India, Pakistan and the local commercial mungbean seeds. The results showed that protein content ranged from 20.04 to $23.76 \%$ fat from 1.12 to $2.85 \%$, fiber from 3.95 to $4.48 \%$, ash from 3.61 to $4.77 \%$ and starch from 42.63 to $50.66 \%$. China and Pakistan verities had the highest concentrations of eight amino acids. Pakistan variety was the highest rarity in the unsaturated fatty acids, whereas the local commercial seeds were the highest in saturated fatty acids content.
\end{abstract}

Keywords: Mungbean, Protein, Fat, Fiber, Amino acids, Fatty acids.

\section{Introduction}

Mungbean as a legume crop has been grown in South and south East Asia since ancient times. It is widely grown in Africa, South America, Australia and other tropical and sub- tropical countries. It is suitable for the hot and humid weather locations. It is being used as a diet for humans and animals (Heller, 2014). Mungbean seeds are a good food and it decreases the risk of various diseases, besides it had health promoting effects, in addition to their nutritive value (Tang et al., 2014). Mungbean is composed of $20-24 \%$ of protein. Albumin and globulin are comprised of $25 \%$ and $60 \%$, respectively. Therefore, due to high protein content and digestibility, the combination of cereals with mungbean its excellent option under low meat availability to maintain protein level in the body.

Anwar et al. (2007) stated that mungbean is a good source of essential fatty acids, minerals and tocopherols. Also, it has a good antioxidant activity. Mungbean seeds composed more than $20 \%$ protein and this protein is rich in the essential amino acids. The high lysine and low methionine amino acid profile of mungbean complement the high carbohydrate and, low lysine /high methionine content of cereals to form a much-balanced amino acid diet (Jaiwal et al., 2001). Mungbean seeds contain around (50-60\%) carbohydrates, trypsin inhibitors, tannins and phytic acid, which is known to have several biological functions such as promoting digestion and eliminating toxins (Lin, 1997). Mendoza et al. (1988) stated that mungbean has high protein content with a good amino acid composition but cysteine and methionine amino acids are present in limited concentrations. The aim of this study is the evaluation of these seeds obtained from four mungbean varieties for their nutritional 
composition and potential for being used for animal feeding supplements.

\section{Material and Methods}

\subsection{Mungbean Seeds}

Mungbean (Vigna radiate L) seeds of the China, Pakistan and India varieties besides the local commercial mungbean seeds were used in this study. The three imported Mungbean varieties and commercial seeds were cleaned manually, milled by a coffee grinder and dried at $68^{\circ} \mathrm{C} / 24 \mathrm{hrs}$ in a drying oven. The dried milled seeds were used to determine the chemical composition of the seeds, which were protein, fat, fiber, ash, free sugars and starch, besides the fatty acids of the oil and amino acids of the protein.

\subsection{Analytical Methods}

\subsubsection{Protein content}

Protein content was determined using Kjeldahl method (method No. 46-10, AACC, 2000) through determination of nitrogen (\%) then multiply by the protein factor (6.25).

\subsubsection{Fat content}

Fat content was determined by the Soxhlet instrument using N-Hexane $(60 \%)$ as an organic solvent (method No.30-10, AACC, 2000).

\subsubsection{Fiber content}

Fiber content was determined according to the AACC method (No.32-10).

\subsubsection{Ash content}

Ash content was determined according to AACC method (NO. 8-01).

\subsubsection{Sugars and starch}

Free sugars and starch contents were determined according to AOAC (1999).

\subsubsection{Total amino acids}

Total amino acids were extracted and estimated according to the method described by Stern et al. (1989). HPLC instrument was used for amino acid estimation is SpectraPhysics Analytical Inc. A0099-600 with spectra focus optical scanning detector and spectra system UV 2000 detector and ultrasphere C18 Beckman column. Analysis was carried out using a gradient of Pico- Tag solvent $\mathrm{A}$ and $\mathrm{B}$ at $40{ }^{\circ} \mathrm{C}$ and a flow rate 1 $\mathrm{ml} / \mathrm{min}$. Detection of the separated PICO -Tag amino acids was done at $254 \mathrm{~nm}$ wavelength Before injecting the sample, the instrument was calibrated by two injections of the standards.

\subsubsection{Fatty acids}

Fatty acids composition were determined using Gas Chromatography Mass Spectrometer, model Shimadzu GCMS-QP 2010. Separation was performed on a capillary column DB5 MS. The carrier gas was Helium with flow rate of $1.20 \mathrm{ml} / \mathrm{min}$. The column temperate was programmed from 70 to $290{ }^{\circ} \mathrm{C}$ at a rate of $15 \mathrm{C} / \mathrm{min}$. A sample volume of 1 $\mu \mathrm{l}$ in hexane was injected using a split mode with the split ratio of 1: 50 .

\subsection{Experimental Design and Statistical Analysis}

Randomized Complete Block Design with four replications was used in this study. The obtained data of all studied characteristics were statistically analyzed using analysis of variance procedures and the means were statistically compared by LSD test at $\mathrm{p} \leq 0.05$ according to El-Nakhlawy (2010) using SAS programme (SAS, 2006).

\section{Results and Discussion}

\subsection{Main Chemical Composition}

The studied seed composition included Protein, fat, fiber and ash. Free sugars and 
starch contents. As shown in Table 1, significant differences were showed between the Protein content of the studied varieties. Protein contents ranged from $23.17 \%$ in the Pakistan variety to $20.04 \%$ in the China variety. Fat (\%) of the mungbean seed ranged from $2.85 \%$ in China variety to $1.12 \%$ in India variety. No significant difference was found between the china seed fat and the local commercial seed fat (Table 1).

Pakistan variety had the highest fiber (\%) with no significant difference from the local commercial seed with values $4.48 \%$ and $4.13 \%$, respectively, while the differences between the china, India and the commercial seeds were insignificant in fat $(\%)$. As for, the ash content, the China variety had the highest (\%) and the Pakistan and India varieties had the lowest ash contents with values of $4.77 \%$, $3.61 \%, 3.83 \%$, respectively as shown in Table 1. In addition, the China variety had the highest free sugars $(8.11 \%)$ followed by India variety $(7.60 \%)$, while the other two varieties had the lowest free sugars.

The main seed composition was the starch, which located with the highest $(\%)$ in the local commercial seeds $(50.66 \%)$ followed by China variety $(46.98 \%)$ and India variety $(44.20 \%)$ and the Pakistan variety was the lowest starch content $(42.63 \%)$ as shown in Table 1. The significant differences between the four seed genotypes might been due to the genetic makeup differences, which reflected on the main chemical composition differences, also due to the genotype- environmental conditions interaction effect. These obtained results were confirmed with the results of Anwar et al. (2007) and Lin (1997).

\subsection{Amino Acid Profile}

In this study, 17 amino acids were determined in the seeds for each studied variety. The obtained results of the amino acids (Table 2) showed that China variety seed had the highest concentrations (\%) of the
Cystine (0.94), Leucine (7.40), Glutamic (18.14), Serine (6.18), Threonine (4.17), Valine (5.07), Phenylalanine (7.12) and Isoleucine (3.96) and the Pakistan variety seed was the highest in Lysine (8.12), Aspartic (12.66), Proline (4.96), Glycine (4.37), Valine (5.18), Methionine (1.94), Phenylalanine (7.30) and Tyrosine (3.14). As for India variety amino acids, the Indian seed protein was the highest in Arginine (8.98), Proline (4.80), Alanine (4.52) and Isoleucine amino acid $(4.02 \%)$. Concerning the local commercial mungbean seeds, the protein consisted of 17 amino acids. This seeds were suprior over the other three varieties in leucine (7.56), Histidine (7.15), Aspartic (12.34), Serine (6.15), Threonine (4.25) and Valine $(5.22 \%)$ amino acids.

\subsection{Fatty Acids}

The amino acid profiles in the four protein sources of mungbean seeds indicated that mungbean seed protein was rich in 15 amino acids, but it was poor in cysteine and methionine amine acids only. The Chine and Pakistan varieties were higher in most protein amino acids than the Indian and local commercial seeds. The obtained result were similar to the results obtained by Tang et al. (2014), Anwar et al. (2007), Jaiwal et al. (2001) and Mendoza et al. (1988).

The fat analysis in the four mungbean verities seeds into fatty acids constituents (Table 3) showed that the unsaturated fatty acids (oleic, linoleic and linolenic acids) compressed around more than $60 \%$ of the oil in four three mungbean varieties, content the local commercial variety seeds that was predominant in linoleic acid only and ranked in the second rank in the other 5 fatty acids as shown in Table 3. These results might have been due to the effect of genotype and the storage conditions of the local commercial mungbean seeds, which adversely affected the fatty acids profile by increasing the 
concentrations of the saturated fatty acids and decreased the concentrations of the unsaturated fatty acids.
These results were similar with the results of Anwar et al. (2007) and Lin (1997).

Table 1. The main chemical components of the four mungbean seed varieties.

\begin{tabular}{lcccc}
\hline \multirow{2}{*}{ Component } & \multicolumn{4}{c}{ Percentage (\%) } \\
\cline { 2 - 5 } & China & Pakistan & India & Local commercial \\
\hline Protein & $20.01^{\mathrm{c}}$ & $23.76^{\mathrm{a}}$ & $21.17^{\mathrm{b}}$ & $20.25^{\mathrm{c}}$ \\
Fat & $2.85^{\mathrm{a}}$ & $1.12^{\mathrm{c}}$ & $1.94^{\mathrm{b}}$ & $2.57^{\mathrm{a}}$ \\
Fiber & $3.95^{\mathrm{b}}$ & $4.48^{\mathrm{a}}$ & $4.05^{\mathrm{b}}$ & $4.13^{\mathrm{a}}$ \\
Ash & $7.77^{\mathrm{a}}$ & $3.61^{\mathrm{c}}$ & $3.83^{\mathrm{c}}$ & $4.45^{\mathrm{b}}$ \\
Free sugars & $8.11^{\mathrm{a}}$ & $7.25^{\mathrm{c}}$ & $7.60^{\mathrm{b}}$ & $7.34^{\mathrm{c}}$ \\
Starch & $46.98^{\mathrm{b}}$ & $42.63^{\mathrm{c}}$ & $44.20^{\mathrm{bc}}$ & $50.66^{\mathrm{a}}$ \\
\hline
\end{tabular}

* Means followed by the same letter are not significantly different according to LSD at $\mathrm{p} \leq 0.05$.

Table 2. Amino acids of the Mungbean seed protein of the 4 varieties.

\begin{tabular}{lcccc}
\hline & & & Percentage (\%) & \\
\cline { 2 - 4 } Amino acid & China & Pakistan & India & Local commercial \\
\hline Lysine & $7.65^{\mathrm{b}^{\mathrm{w}}}$ & $8.12^{\mathrm{a}}$ & $7.05^{\mathrm{c}}$ & $6.17^{\mathrm{d}}$ \\
Cysteine & $0.99^{\mathrm{a}}$ & $0.63^{\mathrm{c}}$ & $0.78^{\mathrm{b}}$ & $0.62^{\mathrm{a}}$ \\
Arginine & $7.63^{\mathrm{b}}$ & $6.36^{\mathrm{d}}$ & $8.95^{\mathrm{a}}$ & $6.97^{\mathrm{a}}$ \\
Leucine & $7.40^{\mathrm{a}}$ & $6.06^{\mathrm{c}}$ & $6.65^{\mathrm{b}}$ & $7.56^{\mathrm{a}}$ \\
Histidine & $5.40^{\mathrm{c}}$ & $6.02^{\mathrm{d}}$ & $6.87^{\mathrm{b}}$ & $7.15^{\mathrm{a}}$ \\
Aspartic & $10.25^{\mathrm{b}}$ & $12.66^{\mathrm{a}}$ & $11.67^{\mathrm{b}}$ & $12.34^{\mathrm{a}}$ \\
Glutamic & $18.14^{\mathrm{a}}$ & $15.32^{\mathrm{c}}$ & $16.54^{\mathrm{b}}$ & $16.92^{\mathrm{b}}$ \\
Serine & $6.18^{\mathrm{a}}$ & $5.60^{\mathrm{b}}$ & $5.04^{\mathrm{c}}$ & $6.15^{\mathrm{a}}$ \\
Threonine & $4.17^{\mathrm{ab}}$ & $3.98^{\mathrm{b}}$ & $3.27^{\mathrm{c}}$ & $4.25^{\mathrm{c}}$ \\
Proline & $4.00^{\mathrm{b}}$ & $4.96^{\mathrm{a}}$ & $4.80^{\mathrm{a}}$ & $3.87^{\mathrm{b}}$ \\
Glycine & $3.09^{\mathrm{c}}$ & $4.37^{\mathrm{a}}$ & $3.73^{\mathrm{b}}$ & $3.15^{\mathrm{c}}$ \\
Alanine & $2.86^{\mathrm{c}}$ & $3.37^{\mathrm{c}}$ & $4.52^{\mathrm{a}}$ & $4.06^{\mathrm{a}}$ \\
Valine & $5.07^{\mathrm{a}}$ & $5.18^{\mathrm{a}}$ & $4.37^{\mathrm{b}}$ & $5.22^{\mathrm{a}}$ \\
Methionine & $1.37^{\mathrm{b}}$ & $1.94^{\mathrm{a}}$ & $1.13^{\mathrm{c}}$ & $1.29^{\mathrm{c}}$ \\
Phenylalanine & $7.12^{\mathrm{a}}$ & $7.30^{\mathrm{a}}$ & $6.18^{\mathrm{b}}$ & $5.59^{\mathrm{b}}$ \\
Isoleucine & $3.96^{\mathrm{a}}$ & $3.12^{\mathrm{c}}$ & $4.02^{\mathrm{a}}$ & $3.37^{\mathrm{b}}$ \\
Tyrosine & $2.11^{\mathrm{d}}$ & $3.14^{\mathrm{a}}$ & $2.80^{\mathrm{c}}$ & $2.95^{\mathrm{bc}}$ \\
\hline
\end{tabular}

* Means followed by the same letter are not significantly different according to LSD at $\mathrm{p} \leq 0.05$.

Table 3. Fatty acids of the mungbean seed lipid of the four varieties.

\begin{tabular}{lllll}
\hline \multirow{2}{*}{ Fatty acid } & \multicolumn{3}{c}{ Percentage (\%) } \\
\cline { 2 - 5 } & \multicolumn{1}{c}{ China } & \multicolumn{1}{c}{ Pakistan } & \multicolumn{1}{c}{ India } & Local commercial \\
\hline Palmitic & $24.00^{\mathrm{b} *}$ & $17.42^{\mathrm{c}}$ & $22.04^{\mathrm{b}}$ & $30.95^{\mathrm{c}}$ \\
Stearic & $12.57^{\mathrm{b}}$ & $14.28^{\mathrm{b}}$ & $13.20^{\mathrm{b}}$ & $22.69^{\mathrm{c}}$ \\
Oleic & $20.83^{\mathrm{b}}$ & $22.67^{\mathrm{b}}$ & $26.37^{\mathrm{a}}$ & $21.32^{\mathrm{b}}$ \\
Linoleic & $28.17^{\mathrm{a}}$ & $26.97^{\mathrm{a}}$ & $20.18^{\mathrm{b}}$ & $12.34^{\mathrm{c}}$ \\
Linolenic & $12.55^{\mathrm{b}}$ & $16.54^{\mathrm{a}}$ & $15.06^{\mathrm{a}}$ & $10.53^{\mathrm{a}}$ \\
Arachidic & $1.88^{\mathrm{b}}$ & $2.16^{\mathrm{a}}$ & $1.35^{\mathrm{c}}$ & $1.06^{\mathrm{a}}$ \\
\hline
\end{tabular}

* Means followed by the same letter are not significantly different according to LSD at $\mathrm{p} \leq 0.05$

\section{Conclusions}

Based on the results obtained from this study it is very evident that mungbean seeds are a good source of the protein, rich in the essential amino acids and are rich in unsaturated fatty acids as well. Accordingly, mungbean had a good nutritive value for humans or animals and can be used as feed supplement to enrich animals' rations to fulfill their maintenance requirements and improve productivity. 


\section{References}

AACC (2000). Approved Methods of the American Association of Cereal Chemists. Amer. Assoc. of Cereal Chem. Inc. St. Panl, Minnesota, USA.

Anwar, F., Latif, S., Przybylski, R., Sultana, B. and Ashraf, M. (2007). Chemical composition and antioxidant activity of seeds of different cultivars of mungbean. Journal of Food Sci, 72 (7): 503-510.

AOAC (1999). Official Methods of Analysis, $17^{\text {th }}$ ed. Washington, Dc: Assoc. of Official Analytical Chemists.

El-Nakhlawy, F.S. (2010). Experimental Design and Analysis in the Scientific Research. Sci. Pub. Center, King Abdulaziz University, Jeddah, Saudi Arabia.

Heller, V.G (2014). Nutritive properties of the mungbean. http://.Jbc.org.

Jaiwal, P.K., Kumar R., Ignacimuthu, S., Potrykus, I. and Sautter, C. (2001). Agrobacterium tumefactions mediated genetic tumeformation of mungbean (Vigns radiate L.) a recalcitrant grain legume. Plant Sci. 61: 239427.

Lin., Y. and Wz, L. (1997). The research of mungbean SOD oral and liquid. Food Sci: 18: 25-26.

Mendoza, E.M., Barroye, C.F., Rodriguez, F.M., Revilleza, M.J.R. and Laurena, A.C.C. (1998). Factors affecting the nutritional quality and acceptability of mungbean. Trans. Nat. Acad. Science \& Tech. (Phils). 10: 305-322.

SAS (2006). Software Statistical Program. SAS Institute Inc., Cary, NC, USA.

Stern, R.J., Kroner, A., Manton, W.I., Reischmann, T., Mansour, M. and Hussein, I.M. (1989). Geochronology of Late Precambrian Hamisana shear zone, Red Sea Hills, Sudan and Egypt. Journal of the Geological Society of London, 146: 1017-1030.

Tang, D., Dong, Y., Ren, H. and He, C. (2014). A review of pytochemistry, metabolite changes and medicinal use of the common food mungbean sprout (vigna radiate). Chemistry Central Journal, 8 (4): 1-9. 
فول المونج: مصدر غذائي مبشر كإضافة لأعلاف حيوانات المزرعة سمير عطية نقادي

قسم زراعة المناطق الجافة، كلبة الأرصاد والبيئة وزراعة المناطق الجافة، جامعة الملك عبد العزبز، المملكة العربية السعودية snagadi@kau.edu.sa

المستخلص. أجريت تلك الدراسة بهدف تقدير المكونات الغذائية الرئيسية والأحماض الأمينية

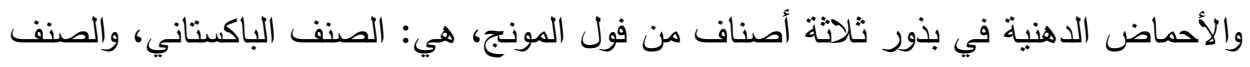
الصيني، والصنف الهندي، بالإضافة إلى بذور فول المونج الموجودة بالسوق المحلي. وقد

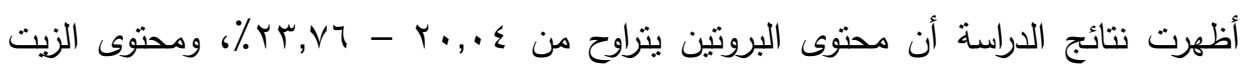

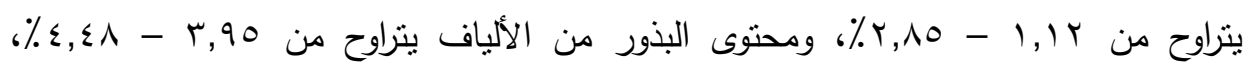

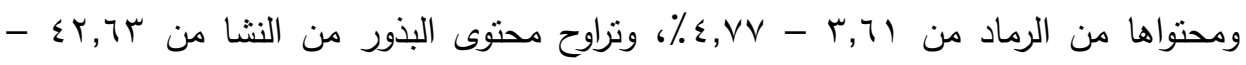
77 , ، ٪ . وكان الصنفان الصيني والباكستاني هما الأعلى في ثمانية من الأحماض الأمينية، وكانا الأعلى أيضًا في تركيز الأحماض الدهنية غير المشبعة، بينما كانت البذور التجارية بالسوق المحلي هي الأعلى في تركيز الأحماض الدهنية المشبعة. كلمات مفتاحية: فول المونج، البرونين، الدهن، الألياف، الأحماض الأمنية، الأحماض الدهنية. 